\title{
Afschaffing van het verpleeghuis komt kwetsbare ouderen ten goede
}

$\mathrm{V}$ eranderingen kunnen zich bliksemsnel voltrekken. Kijk naar het aardgas: wie had tien jaar geleden gedacht dat er een tijd zou komen dat we in razend tempo 'van het gas af zouden gaan'? In de verpleeghuiszorg hebben we al een omslag gezien van enkel grootschalige instellingen naar meer kleinschalig wonen. Is het nu niet tijd voor een volgende stap? Het verpleeghuis naar de geschiedenis verwijzen? Maar wat moeten we dan?

Verpleeghuizen hebben lang een goede functie vervuld in onze samenleving. De vraag is echter of de nadelen ervan niet te groot beginnen te worden. De belangrijkste rol van het verpleeghuis was om somatisch of psychogeriatrisch kwetsbare mensen een veilige verblijfsomgeving te bieden. Die rol heeft het nog steeds en daarom lijkt het op het eerste gezicht ook onzinnig om het verpleeghuis te willen opheffen: er zijn toch heel veel ouderen die verpleging nodig hebben, die verzorgd en begeleid moeten worden?

Dat is waar, maar moet dat op plaatsen gebeuren waar veel ouderen bij elkaar wonen? Ondanks aanzetten in bepaalde instellingen om hierin verbetering te brengen, zijn bewoners in het verpleeghuis doorgaans afgesneden van hun 'thuisfront'. Dat betekent: minder tot geen contact met vrienden en kennissen, te weinig om handen hebben, afstand doen van dingen waaraan men gehecht is. De verschijnselen van hospitalisatie nemen in het verpleeghuis regelmatig forse vormen aan. Daarbij komt dat het verpleeghuis kwetsbare ouderen omgeeft met een kolossale infrastructuur die gepaard gaat met navenante overheadkosten. En voor wat precies? Om mensen die er 24/7 verblijven dagelijks adl-zorg te bieden en een vangnet van medische zorg, terwijl de zeeën van tijd die overblijven bijna 'leeg' zijn? Ja, er wordt af en toe een activiteit aangeboden, maar die sluit slechts zeer zelden aan bij de interesses en hobby's die mensen hadden. Het verpleeghuis is kortom een zeldzaam inefficiënte en ondoelmatige manier om kwetsbare ouderen zorg en begeleiding te bieden en hun kwaliteit van leven overeind te houden.

Een ander groot nadeel is dat mensen in het verpleeghuis worden opgenomen zonder dat er bij plaatsing veel rekening mee wordt gehouden dat voor specifieke doelgroepen een gespecialiseerd aanbod gewenst is. Neem het gegeven dat er steeds meer mensen met cognitieve en/of psychiatrische klachten in het somatisch verpleeghuis wonen. Los van het feit dat het niet mogelijk lijkt invloed uit te oefenen op de instroom van mensen met dergelijke klachten, wordt er in de sector überhaupt weinig tot geen aandacht besteed aan deze problematiek. Verpleeghuizen beschikken in tegenstelling tot (psychiatrische) ziekenhuizen en instellingen voor mensen met een verstandelijke beperking intern over weinig specialistische kennis. En het benutten van het wel aanwezige vakmanschap wordt ernstig beknot door een woud van overbodige regels. Extern zijn wel allerlei specialistische vormen van zorg te bedenken, bijvoorbeeld nachtopvang voor mensen die 's nachts onrustig zijn (een veel aangevoerde reden voor opname in een verpleeghuis). Of een interventieteam in de wijk voor mensen met dementie en gedragsproblemen, aangevuld met de mogelijkheid van een korte opname waarbij allerlei specialisten een goede benadering voor dit gedrag bepalen. Op dit moment zien we een zeker momentum ontstaan door de inzet van de overheid om mensen langer thuis te laten wonen en de publieke aandacht voor een dementievriendelijke samenleving met veel ondersteuning door allerlei maatschappelijke partijen en de buurt. Willen we echt af van de ondoelmatige en dure eenheidsworst die het verpleeghuis in veel gevallen is, dan is nu het moment om door te pakken:

- hef het verpleeghuis op;

- creëer op lokaal/regionaal niveau kleine units waar mensen kortstondig kunnen worden onderzocht en behandeld/gestabiliseerd; - vorm in elke wijk kleinschalige verblijfseenheden waar deze mensen vervolgens in hun eigen omgeving kunnen worden verpleegd totdat zij terug kunnen naar huis.

Dit laatste zal in sommige gevallen niet mogelijk zijn, maar ook dan zullen kwetsbare ouderen meer ingebed blijven in hun eigen sociale netwerk. Het kan beter, het kan goedkoper, hef op dat verpleeghuis!

THEO HAZELHOF IS REDACTEUR VAN DENKBEELD EN PSYCHOLOOG IN DE OUDERENZORG. 